ISSN: 2224-0616

OPEN 2 ACCESS

Int. J. Agril. Res. Innov. Tech. 10(2): 84-90, December 2020 Available online at https://ijarit.webs.com DOI: https://doi.org/10.3329/ijarit.v10i2.51581 https://www.banglajol.info/index.php/IJARIT

\title{
Investigation of soil properties and nutrients in agricultural practiced land in Tangail, Bangladesh
}

\author{
M.S. Islam*, T. Nusrat, M.R. Jamil, F. Yesmin, M.H. Kabir and R.H. Rimi \\ Received 10 August 2020, Revised 23 November 2020, Accepted 24 December 2020, Published online 31 December 2020
}

\begin{abstract}
A B S T R A C T
The study investigated on soil nutrients in agriculture practiced high, medium high, medium low and low land at Kalihati upazila of Tangail district during October 2017 to June 2018. Thirty soil samples were collected from different land types at the study area and analyzed at Soil Resource Development Institute (SRDI) to determine soil nutrient status. The soil parameters under investigation included $\mathrm{pH}$, organic matter $(\mathrm{OM})$, total nitrogen $(\mathrm{N})$, available phosphorus $(\mathrm{P})$, available zinc $(\mathrm{Zn})$, available iron $(\mathrm{Fe})$, available manganese $(\mathrm{Mn})$, available boron (B), exchangeable potassium (K), exchangeable calcium (Ca) and exchangeable magnesium (Mg). Results indicated that many of the soil nutrient levels decreased such as $\mathrm{pH}$ (5.63 to 6.40), P (3.50 to $23.20 \mu \mathrm{g} \mathrm{g}^{-1}$ ), $\mathrm{Zn}$ (3.27 to $\left.3.60 \mu \mathrm{g} \mathrm{g}^{-1}\right), \mathrm{Mn}$ (21.12 to $\left.57.90 \mu \mathrm{g} \mathrm{g}^{-1}\right), \mathrm{B}\left(0.17\right.$ to $\left.0.60 \mu \mathrm{g} \mathrm{g}^{-1}\right), \mathrm{K}$ (0.18 to $\left.0.30 \mathrm{meq} 1 \mathrm{oog}^{-1}\right)$ and $\mathrm{Ca}(5.75$ to 9.10 meq $10^{-1}$ ). On the contrary, the average content of OM (2.30 to 1.40\%), Fe (248.22 to $\left.161.10 \mu \mathrm{g} \mathrm{g}^{-1}\right)$ and $\mathrm{Mg}$ (2.07 to $1.80 \mathrm{meq}^{100 \mathrm{~g}^{-1}}$ ) were increased. Total $\mathrm{N}$ content status did not change much (0.12\%). Soil nutrients like those that available $\mathrm{Zn}, \mathrm{Fe}, \mathrm{Mn}$ and $\mathrm{Mg}$ contents were found above optimum level (very high) but $\mathrm{OM}$ and $\mathrm{N}$ status found below optimum level (low, very low and medium). Nutrient concentrations below optimum levels may limit crop yield. Updated knowledge about soil nutrient status needs to be provided for the farmers so that they can use necessary amount of fertilizers and avoid applying excess amount of fertilizers.
\end{abstract}

Keywords: Nutrients, Land type, Crops production, Soil and Agriculture.

Department of Environmental Science and Resource Management, Mawlana Bhashani Science and Technology University, Tangail-1902, Bangladesh.

*Corresponding author's email: islammstazu@yahoo.com (M.S. Islam)

Cite this article as: Islam, M.S., Nusrat, T., Jamil, M.R., Yesmin, F., Kabir, M.H. and Rimi, R.H. 2020. Investigation of soil properties and nutrients in agricultural practiced land in Tangail, Bangladesh. Int. J. Agril. Res. Innov. Tech. 10(2): 84-90. https://doi.org/10.3329/ijarit.v10i2.51581

\section{Introduction}

The main challenge of agriculture is to provide enough food for the rapidly increasing population of the country (Shah et al., 2008). Farmers desperately try to increase crop yield by applying additional inorganic fertilizers, and pesticides for increasing cropping intensity, where application of excessive amount of a particular fertilizer may hinder availability of other nutrients. Our farmers use fertilizers without knowing about the inherent nutrient status of the soil. Often extra fertilizers and pesticides are used carelessly and inefficiently. Limiting these problems need timely assessment of the soil nutrient at the field level (Bhuiya et al., 1974).

Soil acts as the storehouse for plant nutrients. In other words, soil is the ultimate source of almost all essential nutrient elements for plant growth. Soil plays a major role in determining the sustainable productivity of an agro-ecosystem. The sustainable productivity of soil mainly depends upon its ability to supply essential nutrients to the growing plants. The deficiency of micronutrients is major constraint to productivity, stability and sustainability of soils (Bell and Dell, 2008). Soil fertility is an important factor, which determines the growth of plant. Soil fertility is determined by the presence or absence of nutrients i.e. macro and 
micronutrients. Although micronutrients are required in minute quantities, they have the same agronomic importance as macronutrients because they play a vital role in the growth of plants (Nazif et al., 2006).

For plants, the essential micronutrients are boron, chlorine, sodium, copper, iron, manganese, zinc, vanadium and molybdenum. These elements are required at trace levels and they can have a toxic effect if present at higher than threshold levels. Among them chlorine, manganese, iron, zinc, vanadium are likely to take part in the photosynthesis process. The micronutrients including iron $(\mathrm{Fe})$, copper $(\mathrm{Cu})$, zinc ( $\mathrm{Zn})$, manganese $(\mathrm{Mn})$, cobalt (Co), nickel (Ni) and sulfur (S) play a very important role in plant growth, productivity, soil fertility and animal nutrition. The micronutrients function in living organism as structural components of cell constituents and its metabolically active compounds. They also help in the maintenance of cellular organization, and in energy transformation in enzyme action (Renwick and Walker, 2008).

The yield of almost all crops is very low in Bangladesh compared to some other developed countries. There are a number of reasons behind such low crop yield in which soil is a dominating factor. The agriculture of Bangladesh has been suffering from various problems such as nutrient deficiency and toxicity of soil, improper soil and crop management, alteration of agricultural land for other uses, insects and disease hazards, and natural calamities (Benson and Clay, 2002). The success or failure of a crop production system primarily depends on plant nutrient in soil, which is either naturally endowed or artificially maintained. The cropping sector of Bangladesh must produce more food to feed the country's ever-growing population. Targeting high yield with a higher cropping intensity is the most logical way to raise the total production from the country's limited land resources. Inorganic, organic and bio-fertilizers are the main sources for replenishing plant nutrients in agricultural soil. However, the problem is that soil is turning barren due to deficiency of different nutrients with prolonged agricultural practices without proper management. Soil analysis is a valuable tool for soil nutrients assessment, soil practices and soil management. However, only few studies found to report the status of soil nutrients at Tangail district and there is a clear need for a soil nutrient assessment for agricultural perspectives. Considering this gap, the study was carried out with the following objectives: i) to assess the soil nutrients status in variable lands of the study area, and ii) to assess the changes in soil nutrient contents with agricultural practices.

\section{Materials and Methods}

\section{Study area}

Tangail district is located in the central part of Bangladesh. Kalihati is one of the upazila of Tangail district located at $24^{\prime} 3833^{\circ} \mathrm{N}$ and $90^{\prime} 0083^{\circ}$ E (Fig. 1). The total area of Kalihati upazila is $2.39 \mathrm{~km}^{2}$ with a total of $3,54,959$ populations (BPC, 2011). Bhuapur and Ghatail upazila on the north, Tangail sadar and Basail upazila on the south, Sakhipur upazila on the east and the Jamuna River on the west surround this upazila. Main crops of the upazila are paddy, wheat, mustard, potato, onion, ginger, garlic, pulse and vegetables. Different Land types were found in this upazila which are classified according to Uddin et al. (2019) shown in Table 1.

Table 1. Classification of land types in Bangladesh based on inundation.

\begin{tabular}{|c|c|c|}
\hline Sl. & Land types & Description \\
\hline 1 & Highland (HL) & Land, which is above the normal flooding level \\
\hline 2 & Medium highland (MHL) & $\begin{array}{l}\text { Land, which is flooded up to about } 90 \mathrm{~cm} \text { deep during the } \\
\text { flooding season }\end{array}$ \\
\hline 3 & Medium lowland (MLL) & $\begin{array}{l}\text { Land, which is flooded, between } 90 \text { and } 180 \mathrm{~cm} \text { deep during } \\
\text { flooding season }\end{array}$ \\
\hline 4 & Lowland (LL) & $\begin{array}{l}\text { Land, which is normally flooded up to between } 180 \text { and } 300 \\
\mathrm{~cm} \text { deep during the flooding season }\end{array}$ \\
\hline 5 & Very lowland (VLL) & $\begin{array}{l}\text { Land, which is normally flooded deeper than } 300 \mathrm{~cm} \text { during } \\
\text { the flooding season }\end{array}$ \\
\hline
\end{tabular}




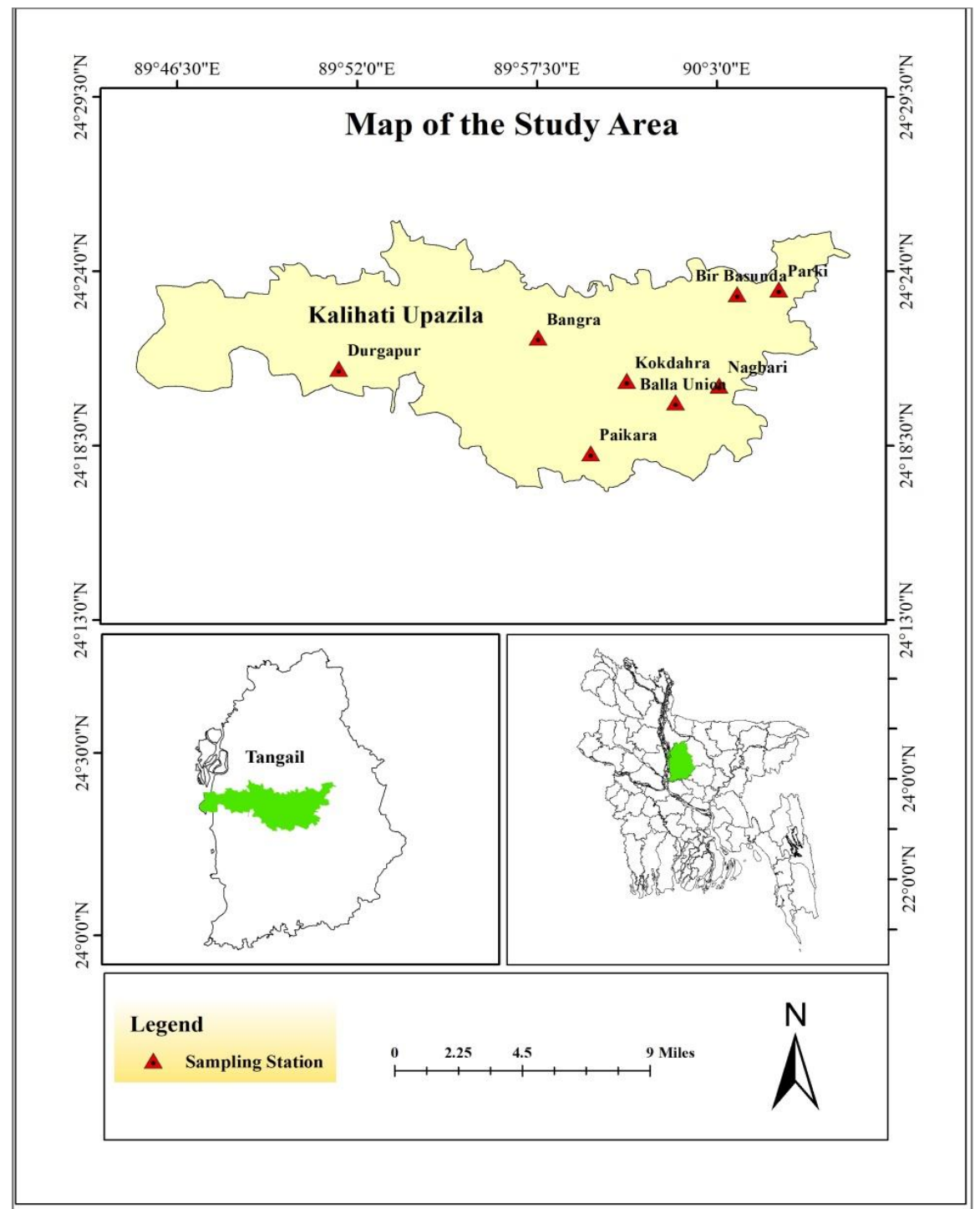

Fig. 1. Map showing the study area in the Kalihati upazila of Tangail district.

\section{Sample collection}

Total 30 soil samples were collected from different land types in the study area to know their nutritional status for agricultural practices. Among them, 6 samples were collected from high land (HL), 9 samples from medium high land (MHL), 9 samples from medium low land (MLL) and 6 samples from low land (LL). The samples were scraped from the top to bottom (o to $10 \mathrm{~cm}$ ) with the help of an auger. Then $250 \mathrm{~g}$ soil was taken to have a representative sample. All samples were placed in sealed polythene bags and labeled with date of collection, location and code number. From the collected samples, the gravels, pebbles, plant roots, leaves etc. were dried in air for 15 days by spreading on a clean piece of polythene bag then samples were mixed well, ground to pass through a 2-mm plastic sieve, and preserved in polythene bags for laboratory analysis.

\section{Sample analysis}

The soil samples were dried in room temperature and carefully transported to the laboratory of
Soil Resource Development Institute (SRDI), Tangail for analysis of soil $\mathrm{pH}$, total organic matter (OM), total nitrogen (N), available phosphorus (P), available zinc ( $\mathrm{Zn})$, available iron $(\mathrm{Fe})$, available manganese $(\mathrm{Mn})$, available boron (B), exchangeable potassium (K), exchangeable calcium (Ca) and exchangeable magnesium (Mg). The soil $\mathrm{pH}$ was determined by digital $\mathrm{pH}$ meter. The OM of soil sample was determined by Walkley and Black's wet oxidation method (Huq and Alam, 2005). Total $\mathrm{N}$ of soil samples were determined by semi-micro Kjeldhal method (Sattar and Rahman, 1987). The available $\mathrm{P}$ of soil was determined by using the Olsen method (Sattar and Rahman, 1987). The available Zn was determined by DTPA method (Roberts, 1971). The available Fe and Mn were determined by DTPA (diethylene-triamine-penta acetic acid) micronutrient extraction method developed by Lindsey and Norvell (1978) using atomic absorption spectrometry (AAS). The available B was determined by hot water extraction method using a dilute calcium chloride solution introduced by Berger and Truog (1939). The exchangeable $\mathrm{K}$ in soil was determined by 
ammonium acetate extraction method (Sattar and Rahman, 1987). The exchangeable $\mathrm{Ca}$ and $\mathrm{Mg}$ of soil samples were determined by EDTA (Ethylenediamene Tetra Acetic Acid) titration method (Huq and Alam, 2005).

\section{Statistical analysis}

After getting the soil test results from SRDI, data were compiled, tabulated and analyzed through Microsoft Office Excel software.

\section{Results and Discussion}

\section{Soil pH}

The soil pH was $6.00,5.82,5.53$ and 5.16 in HL, MHL, MLL and LL, respectively (Table 2 and 3 ). The $\mathrm{pH}$ values were indicated slightly acidic soil in HL and MHL, whereas strongly acidic soil in MLL and LL. Prodhan (2010) reported that the soil $\mathrm{pH}$ increase with increasing depth. Probably due to removal of basic soil materials like $\mathrm{CaCO}_{3}$ and $\mathrm{MgCO}_{3}$ from upper soil layer with simultaneous accumulation in lower layer through leaching. The $\mathrm{pH}$ status of the study area's soil ranged from 4.85 to 6.74 . Bhuiyan (1988) reported that the $\mathrm{pH}$ of different soil series of Bangladesh ranged from 4.4 to 8.o. Average soil pH was 5.63 indicated slightly acidic in nature in the study area.

\section{Total organic matter (OM)}

The soil OM in HL, MHL, MLL and LL was 2.00, $2.15,2.40$ and $2.64 \%$, respectively in the study area (Table 2 and 3). The OM indicated medium in status in all the land types. The OM status ranged from 1.86 to $3.65 \%$ with an average of $2.30 \%$ i.e., medium status in nature. About 3.4\% organic matter in soil is suitable for almost allagricultural crop production (Ahmed et al., 2018). Higher oxidation rate of plant and animal residues by relatively higher temperature may have contributed to such low levels of OM (Khan et al., 2002). The SRDI (2009) reported that the organic matter of Balla union agricultural soils of Kalihati upazila ranged from 2.20 to $2.70 \%$.

\section{Total nitrogen (TN)}

The TN was 0.10, 0.11, 0.12 and $0.13 \%$ in all types of land in the study area indicated low nutrient status that is below the optimum level (Table 2 and 4). The optimum value of $\mathrm{TN}$ is 0.27 to $0.36 \%$ for agricultural land (Ahmed et al., 2018). The total nitrogen in soil ranged from 0.09 to $0.18 \%$ with a mean of $0.12 \%$ (Table 4 ) which was below the optimum level. Below optimum level (very low, low and medium) nutrient status, makes soil nutrient deficient and consequently limits crop yield (Heckman, 2006). The TN deficiency can be due to de-nitrification, leaching, immobilization of nitrogen from the soil. Other reasons may include intensive crop cultivation, and imbalanced use of fertilizer. For instance, Razzaque et al. (1998) showed that the nitrogen content in non-irrigated surface and sub-surface soils of Ghatail and Kalihati upazila were 0.06 to $0.29 \%$ and 0.03 to $0.22 \%$, respectively. Hossain et al. (2003) observed that the total nitrogen content decreased with increasing the depth of soils. In old Brahmaputra floodplain soil, the total nitrogen varied from 0.038 to $0.100 \%$ and Madhupur tract from 0.010 to $0.082 \%$ under different cropping patterns and tillage.

Table 2. Soil nutrients status in agricultural practiced land at Kalihati upazila, Tangail.

\begin{tabular}{|c|c|c|c|c|}
\hline \multirow[t]{2}{*}{ Soil nutrients } & \multicolumn{4}{|c|}{ Land types } \\
\hline & HL $(n=6)$ & MHL $(n=9)$ & $\operatorname{MLL}(\mathrm{n}=9)$ & $\mathrm{LL}(\mathrm{n}=6)$ \\
\hline Soil pH & $6.00 \pm 0.54$ & $5.82 \pm 0.40$ & $5.53 \pm 0.23$ & $5.16 \pm 0.16$ \\
\hline Status & SlA & SlA & StA & StA \\
\hline OM (\%) & $2.00 \pm 0.12$ & $2.15 \pm 0.26$ & $2.40 \pm 0.49$ & $2.64 \pm 0.71$ \\
\hline Status & M & M & M & M \\
\hline $\mathrm{TN}(\%)$ & $0.10 \pm 0.01$ & $0.11 \pm 0.01$ & $0.12 \pm 0.02$ & $0.13 \pm 0.03$ \\
\hline Status & $\mathrm{L}$ & L & $\mathrm{L}$ & $\mathrm{L}$ \\
\hline $\mathrm{AP}\left(\mu \mathrm{g} \mathrm{g}^{-1}\right)$ & $8.20 \pm 4.96$ & $3.26 \pm 1.62$ & $1.88 \pm 0.83$ & $2.04 \pm 1.00$ \\
\hline Status & OP & $\mathrm{VL}$ & VL & VL \\
\hline $\mathrm{Zn}\left(\mu \mathrm{g} \mathrm{g}^{-\mathbf{1}}\right)$ & $2.80 \pm 1.98$ & $3.80 \pm 1.22$ & $3.02 \pm 1.35$ & $3 \cdot 39 \pm 1.17$ \\
\hline Status & $\mathrm{VH}$ & VH & VH & $\mathrm{VH}$ \\
\hline $\mathrm{Fe}\left(\mu \mathrm{g} \mathrm{g}^{-1}\right)$ & $168.10 \pm 82.50$ & $192.80 \pm 43.70$ & $288.80 \pm 45.19$ & $365.10 \pm 50.59$ \\
\hline Status & $\mathrm{VH}$ & $\mathrm{VH}$ & $\mathrm{VH}$ & VH \\
\hline $\operatorname{Mn}\left(\mu g g^{-1}\right)$ & $25.60 \pm 11.21$ & $15.74 \pm 8.70$ & $25.25 \pm 15.10$ & $18.49 \pm 9.93$ \\
\hline Status & $\mathrm{VH}$ & $\mathrm{VH}$ & $\mathrm{VH}$ & $\mathrm{VH}$ \\
\hline $\mathrm{B}\left(\mu \mathrm{g} \mathrm{g}^{-1}\right)$ & $0.10 \pm 0.03$ & $0.17 \pm 0.05$ & $0.18 \pm 0.04$ & $0.15 \pm 0.05$ \\
\hline Status & VL & $\mathrm{L}$ & $\mathrm{L}$ & VL \\
\hline $\mathrm{K}\left(\right.$ meq 10og-1 $\left.^{-1}\right)$ & $0.10 \pm 0.02$ & $0.15 \pm 0.05$ & $0.21 \pm 0.06$ & $0.28 \pm 0.05$ \\
\hline Status & $\mathrm{L}$ & $\mathrm{L}$ & M & OP \\
\hline $\mathrm{Ca}\left(\mathrm{meq} 1 \mathrm{oog}^{-1}\right)$ & $4.80 \pm 1.12$ & $5.22 \pm 1.15$ & $6.59 \pm 1.49$ & $6.25 \pm 1.07$ \\
\hline Status & $\mathrm{OP}$ & OP & $\mathrm{H}$ & $\mathrm{H}$ \\
\hline $\operatorname{Mg}\left(\right.$ meq $\left.100 g^{-1}\right)$ & $2.00 \pm 0.43$ & $2.05 \pm 0.37$ & $2.11 \pm 0.27$ & $2.12 \pm 0.25$ \\
\hline Status & $\mathrm{VH}$ & $\mathrm{VH}$ & VH & $\mathrm{VH}$ \\
\hline
\end{tabular}

Note: H=High, L=Low, M=Medium, N=Neutral, OP=Optimum, SlA=Slightly Acidic, StA=Strongly Acidic, $V H=$ Very High, $V L=$ Very Low. 


\section{Available phosphorus (P)}

In HL soil, available $\mathrm{P}$ was $8.20 \mu \mathrm{g} \mathrm{g}^{-1}$, whereas MHL, MLL and LL with 3.26, 1.88 and $2.04 \mu \mathrm{g} \mathrm{g}^{-1}$, respectively (Table 2). The mean available $\mathrm{P}$ was $3.50 \mu \mathrm{g} \mathrm{g}^{-1}$, which indicated very low status of nutrient (Table 4). The optimum nutritional level of available $\mathrm{P}$ in soil is 18.1 to $24.0 \mu \mathrm{g} \mathrm{g}^{-1}$ for agriculture practice in Bangladesh (Ahmed et al., 2018). Portch (1984) reported that the $41 \%$ soils of Bangladesh contained phosphorous with below critical level and $35 \%$ below optimum level. The available phosphorous content varied with different location and layer of soil profile.

\section{Available zinc (Zn)}

The available $\mathrm{Zn}$ in HL, MHL, MLL and LL were $2.80,3.80,3.02$ and $3.39 \mu \mathrm{g} \mathrm{g}{ }^{-1}$, respectively (Table 2). The $\mathrm{Zn}$ levels ranged from 0.94 to 6.35 $\mu \mathrm{g} \mathrm{g}^{-1}$ with a mean of $3.25 \mu \mathrm{g} \mathrm{g}^{-1}$ (Table 1) which was above the optimum (very high) range and so was considered more than adequate for crop yield (Table 4). Therefore, addition of the nutrient has a very low probability of getting an economic crop yield response. If more nutrients are added, there is a possibility of getting a negative effect on the crops due to excessive $\mathrm{Zn}$ (Heckman, 2006). Average $\mathrm{Zn}$ levels in all types of lands slightly decreased. Jahiruddin et al. (1981) reported Zn deficiency in some soils and generally in submerged soils.

Table 3. Classification of soil pH and organic matter according to Ahmed et al. (2018).

\begin{tabular}{|c|c|c|c|}
\hline Standard of soil pH & & \multicolumn{2}{c|}{ Standard of soil organic matter (\%) } \\
\hline Value & Soil reaction class & Value & Status \\
\hline$<4.5$ & Very strongly acidic & $<1.00$ & Very low \\
\hline $4.5-5.5$ & Strongly acidic & $1.00-1.70$ & Low \\
\hline $5.6-6.5$ & Slightly acidic & $1.71-3.40$ & Medium \\
\hline $6.6-7.3$ & Neutral & $3.41-5.50$ & High \\
\hline $7.4-8.4$ & Slightly alkaline & $>5 \cdot 50$ & Very high \\
\hline $8.5-9.0$ & Strongly alkaline & - & - \\
\hline \hline$>9.0$ & Very strongly alkaline & - & - \\
\hline
\end{tabular}

\section{Available iron (Fe)}

In the study area, the mean available iron was found in all types of land (HL, MHL, MLL and LL) at very high levels (Table 4). The iron content ranged from 56.58 to $411.70 \mu \mathrm{g} \mathrm{g}^{-1}$ with an average of $253.70 \mu^{-1} \mathrm{~g}^{-1}$ in study area (Table 2). The optimum level of available Fe is 9.1 to $12.0 \mu \mathrm{g}$ $\mathrm{g}^{-1}$, which is comparatively high and adequate to crop yield (Ahmed et al., 2018). Therefore, there is no need to apply any additional available Fe in these lands. The SRDI (2001b) reported that the Fe content of highland, medium highland and medium lowland under Mymensingh sadar upazila were 91,87 and $146 \mu \mathrm{g} \mathrm{g}^{-1}$, respectively. The SRDI (2001b) reported that suitable Fe content in soil is 9.1 to $12.0 \mu \mathrm{g} \mathrm{g}^{-1}$ for crop production. Hussain (1992) reported that the soils of Madhupur tract contain high amount of iron and aluminum, which are highly aggregated.

\section{Available manganese (Mn)}

The available Mn content in HL, MHL, MLL and LL were $25.60,15.74,25.25$ and $18.49 \mu \mathrm{g} \mathrm{g}^{-1}$, respectively (Table 2). The SRDI (2001b) reported that the Mn content of HL, MHL and MLL under Mymensingh sadar upazila were 45.10, 49.80 and $2.31 \mu \mathrm{g} \mathrm{g} \mathrm{g}^{-1}$, respectively. Razzaque et al. (1998) observed that the Mn content of the non-irrigated surface and subsurface soil of Ghatail and Kalihati upazila were 32.5 to $162.5 \mu \mathrm{g} \mathrm{g}^{-1}$ and 36.3 to $124.0 \mu \mathrm{g} \mathrm{g}{ }^{-1}$, respectively. The optimum content of available $\mathrm{Mn}$ in soil is 2.26 to $3.00 \mu \mathrm{g} \mathrm{g}^{-1}$ for agricultural activities (Ahmed et al., 2018). However, the mean status of Mn of the study area soil was $21.27 \mu \mathrm{g} \mathrm{g}^{-1}$, which indicated very high content of available Mn (Table 4). Average content is higher than optimum level and so addition of available Mn was not required in these lands.

Table 4. Status of soil nutritional level according to Ahmed et al. (2018).

\begin{tabular}{|c|c|c|c|c|c|c|}
\hline \multirow{2}{*}{ Nutrients } & \multicolumn{6}{|c|}{ Nutrients status } \\
\hline & Very low & Low & Medium & Optimum & High & Very high \\
\hline $\mathrm{N}(\%)$ & $<0.090$ & $0.091-0.18$ & $0.081-0.270$ & $0.271-0.36$ & $0.361-0.450$ & $>0.450$ \\
\hline $\mathrm{P}\left(\mu \mathrm{g} \mathrm{g}^{-1}\right)$ & $<6.000$ & $6.100-12.00$ & $12.100-18.000$ & $18.100-24.00$ & $24.100-30.000$ & $>30.000$ \\
\hline $\mathrm{Z}\left(\mu \mathrm{g} \mathrm{g}^{-1}\right)$ & $<0.450$ & $0.451-0.90$ & $0.910-1.350$ & $1.351-1.80$ & $1.810-2.250$ & $>2.250$ \\
\hline $\mathrm{Fe}\left(\mu \mathrm{g} \mathrm{g}^{-1}\right)$ & $<3.000$ & $3.100-6.00$ & $6.100-9.000$ & $9.100-12.00$ & $12.100-15.000$ & $>15.000$ \\
\hline $\operatorname{Mn}\left(\mu \mathrm{g} \mathrm{g}^{-1}\right)$ & $<0.750$ & $0.760-1.50$ & $1.510-2.250$ & $2.260-3.00$ & $3.100-3.750$ & $>3.750$ \\
\hline $\mathrm{B}\left(\mu \mathrm{g} \mathrm{g}^{-1}\right)$ & $<0.150$ & $0.151-0.30$ & $0.310-0.450$ & $0.451-0.600$ & $0.610-0.750$ & $>0.750$ \\
\hline $\mathrm{K}\left(\right.$ meq 10og $\left.^{-1}\right)$ & $<0.075$ & $0.076-0.15$ & $0.151-0.225$ & $0.226-0.300$ & $0.310-0.375$ & $>0.375$ \\
\hline $\mathrm{Ca}\left(\right.$ meq $\left.1 \mathrm{oog}^{-1}\right)$ & $<1.500$ & $1.510-3.00$ & $3.010-4.500$ & $4.510-6.00$ & $6.010-7.500$ & $>7.500$ \\
\hline $\mathrm{Mg}$ (meq 100g-1) & $<0.375$ & $0.376-0.75$ & $0.751-1.125$ & $1.126-1.50$ & $1.510-1.875$ & $>1.875$ \\
\hline
\end{tabular}




\section{Available boron (B)}

The available B in soil was $0.10,0.17,0.18$ and $0.15 \mu \mathrm{g} \mathrm{g}^{-1}$ in HL, MHL, MLL and LL, respectively (Table 2). The optimum content of available B in soil is 0.45 to $0.60 \mu \mathrm{g} \mathrm{g}^{-1}$ (Ahmed et al., 2018). The available B ranged from 0.10 to $0.25 \mu \mathrm{g} \mathrm{g}{ }^{-1}$ with an average of $0.15 \mu \mathrm{g} \mathrm{g}^{-1}$ indicated low content of nutritional status (Table 4). Available B content at the study area was lower than optimum level. It might be due to intensive cropping pattern and imbalance use of fertilizer. At such low levels of available B, crop yield might be limited. The SRDI (2005) reported the most B deficient areas are Dinajpur, Rangpur, Bogura, Sirajganj, Comilla and Sylhet.

\section{Exchangeable potassium (K)}

In the study area, the exchangeable $\mathrm{K}$ in soil were $0.10,0.15,0.21$ and $0.28 \mathrm{meq}^{100 \mathrm{O}^{-1}}$ in HL, MHL, MLL and LL area, respectively (Table 2). The optimum content of exchangeable $\mathrm{K}$ in soil is $0.27 \mathrm{meq}^{100 \mathrm{~g}^{-1}}$ (Ahmed et al., 2018). In HL and MHL, low content of exchangeable $\mathrm{K}$ was found. In MLL and LL area, medium and optimum exchangeable K status was found (Table 2 and 4 ). The mean $\mathrm{K}$ content was found low 0.19 meq

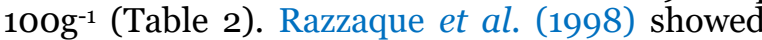
that $\mathrm{K}$ content of some non-irrigated surface and sub-surface soils of Ghatail and Kalihati upazila were 0.06 to 0.68 and 0.10 to 0.47 meq $10^{-1}$, respectively. Ghosh and Biswas (1978) reported that the continuous cropping without $\mathrm{K}$ application was found to decrease the content of exchangeable $\mathrm{K}$ appreciably and increase the influence of $\mathrm{K}$ progressively.

\section{Exchangeable calcium (Ca)}

The soil exchangeable Ca content in HL, MHL, MLL and LL area were 4.80, 5.22, 6.59 and 6.25 meq $1^{100 g^{-1}}$, respectively (Table 2). The optimum content of exchangeable $\mathrm{Ca}$ is 4.51 meq $1 \mathrm{OOg}^{-1}$ (Ahmed et al., 2018). The mean Ca content was found optimum as $5.72 \mathrm{meq}^{100 \mathrm{~g}^{-1}}$ (Table 4). In all types of lands in Kalihati upazila, soil exchangeable $\mathrm{Ca}$ was decreasing. The SRDI (2001b) reported that the exchangeable $\mathrm{Ca}$ content of HL, MHL and MLL under Madhupur upazila were $0.9,1.3$ and 1.3 meq $10^{-1}$, respectively.

\section{Exchangeable magnesium (Mg)}

The soil exchangeable Mg content were 2.00,

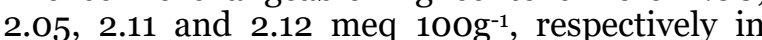
highland, medium highland, medium lowland and lowland (Table 2). In all land types except low land areas, exchangeable Mg content status was higher (Table 4). The optimum value of $\mathrm{Mg}$ in soil is 1.13 to 1.50 meq $1^{100 g^{-1}}$ (Ahmed et al., 2018). The mean Mg value was found very high as 2.07 meq $10^{-1}$ (Table 2 and 4). The Mg was more than adequate and at very high levels, there is a possibility of a negative impact on the crop if nutrients are added (Heckman, 2006). Akter et al. (2012) found that the Madhupur tract exchangeable magnesium was 2.76 meq $100 \mathrm{~g}^{-1}$ soil.

\section{Conclusions}

Findings of this study concluded that most of the nutrients were above optimum levels and so there was no need for using additional supplements for these nutrients. The soil $\mathrm{pH}$, available $\mathrm{P}$, available $\mathrm{Zn}$, available $\mathrm{Mn}$, available $\mathrm{B}$, exchangeable $\mathrm{K}$ and exchangeable Ca decreased when compared with optimum level. On the other hand, the average $\mathrm{OM}$, available $\mathrm{Fe}$ and exchangeable $\mathrm{Mg}$ contents were increased than optimum. While, some of the nutrients analyzed were at the optimum level suitable for crop yield; few nutrients were below optimum level causing crop yield reduction. Intensive crop production, imbalance use of fertilizer, and cropping pattern change over time might have contributed to nutrient deficiencies in the soil. Consequently extra fertilizer application was needed for expected level of crop production. To minimize loss of soil nutrients and degradation of soil quality, this study recommended few actions including: i) proper steps should be taken to provide knowledge to the farmers about using fertilizer at proper dose; ii) increase essential soil nutrients of OM, N, P in agricultural lands using appropriate fertilizers; iii) develop farmers' awareness through intensive training; iv) improving capacity building and involvement of GO's and NGO's to support farmers; and v) government should facilitate availability of quality fertilizers and provide information about correct dose for application at different soil regions.

\section{Acknowledgements}

Sincere gratitude to Mr. Utpol Kumar (Scientific Officer, Soil Resource Development Institute, Tangail) for his kind support during the study period.

\section{References}

Ahmed, S., Jahiruddin, M., Razia, M.S., Begum, R.A., Biswas, J.C., Rahman, A.S.M.M., Ali, M.M., Islam, K.M.S., Hossain, M.M., Gani, M.N., Hossain, G.M.A. and Satter, M.A. 2018. Fertilizer recommendation guide2018. Bangladesh Agricultural Research Council (BARC), Farmgate, Dhaka 1215, Bangladesh. p. 223.

Akter, M., Alam, M.S., Chowdhury, A.K. and Chowdhury, M.A.H. 2012. Soil organic matter, mineral, nutrients and heavy metals status of some selected regions of Bangladesh. J. Env. Sci. Nat. Res. 5(2): 1-9. https://doi.org/10.3329/jesnr.v5i2.14570

Bell, R.W. and Dell, B. 2008. Micronutrients for sustainable food, feed, fiber and bioenergy production. International Fertilizer Industry Association (IFA), Paris, France. pp. 1-10.

Benson, C. and Clay, E. 2002. Disaster management facility. Bangladesh: disasters and public finance. Disaster risk management working paper series 6 , The World Bank, Washington, D.C. p. 130. 
Berger, K.C. and Truog, E. 1939. Boron determination in soils and plants. Ind. Eng. Chem. Anal. Edu. 11: 540-545. https://doi.org/10.1021/ac50138aoo7

Bhuiya, Z.H., Sattar, M.A. and Islam, M.S. 1974 Physical and chemical studies of some soils of Bangladesh.J. Asiatic Soc. Bangladesh. 19: 11-21.

Bhuiyan, N.I. 1988. Coordinated project on potassium studies progress report (198788). BRRI (Bangladesh Rice Research Institution), Joydevpur, Gazipur. pp. 1-45.

BPC (Bangladesh Population Census). 2011. Bangladesh Bureau of statistics; district statistics survey report of (Kalihati upazila) Tangail, Bangladesh. p. 135 .

Ghosh, A.B. and Biswas, C.R. 1978. Proc. Int. potassium symp. Potash Res. Inst. New Delhi, India. pp. 379-390.

Heckman, J.R. 2006. Soil fertility test interpretation: phosphorus, potassium, magnesium and calcium. Rutgers Cooperative Extension, New Jersey Agricultural Experiment Station, Rutgers, The State University of New Jersey, New Brunswick, USA. pp. 1-4.

Hossain, A., Hossain, A.K.M.M., Rahman, M.S. Rahman, M.M., Chowdhury, M.A.H. and Khan, M.S.H. 2003. Effect of tillage practices on soil properties under different cropping patterns. J. Sci. Tech. 1: 43-48.

Huq, S.M.I. and Alam, M.D. 2005. A handbook on analysis of soil, plant and water. Bangladesh- Australia Centre for Environmental Research (BACER-DU), Dhaka. pp. 61-117.

Hussain, M.S. 1992. Soil classification: with special reference to the soils of Bangladesh. University of Dhaka. pp. 20-24.

Jahiruddin, M., Bhuiya, Z.H., Haque, M.S. and Rahaman, L. 1981. Effect of rates and methods of zinc application on rice. Madras Agril. J. 68: 211-216.

Khan, H.R., Bhuiyan, M.M.A., Kabir, S.M., Ahmed, F., Syeed, S.M.A. and Blume, H.P. 2002. The assessment and management of acid sulfate soils in Bangladesh in relation to crop production. World Scientific Publishing Co. Pvt. Ltd., UK. pp. 254-262. https://doi.org/10.1142/9789812795380_0022

Lindsey, W.L. and Norvell, W.A. 1978. Development of a DTPA soil test for zinc, manganese, iron and copper. American $J$. Soc. Soil Sci. 42: 421-428. https://doi.org/10.2136/sssaj1978.03615995004 200030009x

Nazif, W., Perveen, S. and Saleem, I. 2006. Status of micronutrients in soils of district Bhimber (Azad Jammu and Kashmir). J. Agril. Biol. Sci. 1(2): 35-40.
Portch, S. 1984. Nutrient status of some of the more important agricultural soils of Bangladesh. pp. 97-106. In: Proceedings of the international symposium on soil test crop response correlation studies. Bangladesh Agricultural Research Council and Soil Science Society of Bangladesh, Dhaka.

Prodhan, R. 2010. Study on the nutrient status of selected major soil series of old Himalayan Piedmont Plain (AEZ-1) of Bangladesh. MS Thesis, Department of Agricultural Chemistry, Bangladesh Agricultural University, Mymensingh-2202. p. 120.

Razzaque, M.A., Shamsuddoha, A.T.M., Khan, M.A. and Zaman, M.W. 1998. Effect of surface and groundwater irrigation on some physicochemical properties of surface and sub-surface soils. J. Agril. Edu. Tech. 1(2): 142-147.

Renwick, A.G. and Walker, R. 2008. Risk assessment of micronutrients. Toxicol. Letters. $180(2)$ : 123-130.

https://doi.org/10.1016/j.toxlet.2008.05.009

Roberts, S. 1971. Methods of soil analysis used in the soil testing laboratory at Oregon State University, USA. p. 27.

Sattar, D.M.A. and M.M. Rahman. 1987. Techniques of soil analysis. MS Thesis, Department of Soil Science, Bangladesh Agricultural University, Mymensingh-2202. pp. 67-124.

Shah, A.L., Rahman, M.S. and Aziz, M.A. 2008. Outlook for fertilizer consumption and food production in Bangladesh. Bangladesh $J$. Agric. Env. 4: 1-8.

SRDI. 2001a. Land and soil resource utilization guide (in Bengali). Upazila Nirdeshika series, Madhupur upazila, Soil Resource Development Institute, Dhaka. pp. 53-58.

SRDI. 2001b. Land and soil resources utilization guide (in Bengali). Thana Nirdeshika series, Mymensingh sadar upazila, Soil Resources Development Institute, Dhaka. pp. 25-35.

SRDI. 2005. Land and soil resources utilization guide (in Bengali). Upazila Nirdeshika Series. Soil Resources Development Institute, Dhaka. pp. 45-63.

SRDI. 2009. Land and soil resources utilization guide (in Bengali). Upazila Nirdeshika series, Sherpur sadar upazila. Soil Resources Development Institute, Dhaka. pp. 73-74.

Uddin, M.J., Hooda, P.S., Mohiuddin, A.S.M., Smith, M. and Waller, M. 2019. Land inundation and cropping intensity influences on organic carbon in the agricultural soils of Bangladesh. Catena. 178: 11-19.

https://doi.org/10.1016/j.catena.2019.03.002 